\title{
ASSESSMENT OF THE KNOWLEDGE, ATTITUDE AND PRACTICE TOWARDS FOOD POISONING OF FOOD HANDLERS IN SOME EGYPTIAN WORKSITES
}

\author{
By \\ ${ }^{1}$ Adel Hakim S, ${ }^{1}$ Mostafa NS and ${ }^{2}$ Abdel-Rahman SM \\ ${ }^{1}$ Department of Community, Environmental \& Occupational Medicine, ${ }^{2}$ Department of Medical Microbiology \\ and Immunology, Faculty of Medicine, Ain Shams University, Cairo, Egypt.
}

\begin{abstract}
Introduction: Food handlers represent an occupational group which plays a major role in the spread of food borne diseases. The risk of food getting contaminated depends largely on the knowledge and practice of proper food hygiene measures among food handlers. Aim of work: To assess the knowledge and practice of food handlers towards food hygiene in addition to identifying the frequency of workers with positive nail culture. Materials and Methods: A cross sectional study including 140 subjects such that 54 worked in the kitchens of Ain Shams University Hospitals and 86 from 16 fast food restaurants were included in the study. Questionnaire and nail swabs for culture were done after obtaining their consent. Results: The study showed that the mean knowledge score was 76.6 \pm 19.6 and the mean practice score was $68.1 \pm 22.4$. Knowledge questions related to the correct method of thawing food and the right place for vegetables and meat in the refrigerator showed less than 50\% correct answers. Practice questions related to not keeping food at room temperature for more than 4 hours and not to continue working if having flu or hand lesions should total correct answers less than $50 \%$. (40.7\%) of those who agreed to give nail swabs showed positive culture with CoNS being the most frequently discovered pathogen. Conclusion: food handlers are an occupational group who need careful supervision and training courses on food hygiene and how to carry on their tasks safely without harming themselves or others.
\end{abstract}

Keywords: Food handlers, Knowledge, Safe practice, Nail swabs, Food poisoning 


\section{Introduction}

Food handlers who are any person who handles food regardless whether he actually prepares or serves it play an important role in the transmission and ultimately prevention of food borne diseases (Isara and Isah, 2009).

Food handlers play a major role in transmitting pathogens from contaminated sources such as transmitting pathogens from raw meat to ready to eat food. Food handlers may also carry some human specific food borne pathogens as hepatitis A, noroviruses, typhoidal salmonella, staphylococcus aureus and shigella species in their hands, cuts or sores, mouth, skin and hair. Food handlers may also shed food borne pathogens as E.coli and non typhoidal salmonella during the infectiousness period or during the recovery period of a gastrointestinal sickness (Adams and Moss, 2008).

Todd et al (2007) formed a workgroup and analyzed 816 food borne outbreaks where food workers have been implicated in the spread of food borne diseases. In their last publication, they found that the most frequently reported food worker errors were handling of food by a person either actively infected by or carrying a pathogen bare-hand contact with food, failure to properly wash hands when necessary, insufficient cleaning of processing or preparation equipment or kitchen tools. Such unhygienic practice would cause contamination of ready to eat food. A study conducted in Malaysia, 2002 which showed that approximately (10-20\%) of food borne disease outbreaks are due to contamination by food handlers (Zain and Naing, 2002)

Food borne diseases are increasing in both developed and developing countries. Diarrheal diseases, mostly caused by food borne microbial pathogens are leading causes of illness and deaths in the developing countries, killing an estimated 1.9 million people annually at the global level (Schlundt et al 2004).

The risk of food getting contaminated depends largely on the health status of the food handlers, their personal hygiene, knowledge and practice of food hygiene (Mead et al, 1999).

\section{Aim of Work}

Therefore, this study aims at evaluating the knowledge and practices of food handlers and its relation with the type of work and work duration. Moreover, it aims at identifying the frequency of workers with positive nail culture from all who agreed to have a nail culture and the types of organisms in these cultures. 


\section{Materials and Methods}

A cross-sectional study was carried out among food handlers. A food handler or food employee is defined by FDA (2013a) as an individual working with unpackaged food, food equipment or utensils or food-contact surfaces. In the current work it included: cooks, cook helpers and waiters.

The study included 140 subjects divided as follows: 54 food handlers working in four departments of Ain Shams University tertiary care hospital in Cairo (pediatrics, surgery, internal medicine and gynecology and obstetrics departments) after obtaining administrative approval from the hospital manager and Institutional Ethics Committee. The rest of subjects (86 workers) were included from 16 fast food restaurants in Cairo. The purpose of the study was explained to the food handlers and their informed consent was taken.

Sample size was calculated using epi info program population survey as 128 based on overall prevalence of intestinal parasite infestation to be $14 \%$ (Mohan, 2001) and the worst acceptable level as $8 \%$ with $95 \%$ confidence interval and $80 \%$ power of the test.
The study was carried out between March to November 2013. The study participants were interviewed using a structured questionnaire. It consisted of demographic details of the food handlers, information related to personal hygiene and personal habits.

The questionnaire also assessed the individual's knowledge, attitude and practices about hygienic food measures.

Ordinary sterile swabs (moistened with sterile saline) had been used to obtain a single finger swab from each food handler, the collected swabs were transferred immediately to microbiology lab and were cultured on Blood agar, and MacConkey's agar plates and then incubated at $37^{\circ} \mathrm{C}$ for 24 hours, Isolates were identified by growth characteristics on respective culture media and by doing biochemical tests following standard procedures according to Colle et al (2007).

\section{Statistical analysis}

Data entry and analysis were performed using SPSS version 17 . The data collected was analyzed by descriptive (frequency distribution tables, mean and standard deviation) as well as inferential analysis (chi square and $t$ test).

No funding sources for this research. 


\section{Results}

Table (1): Demographic characteristics of the study sample:

\begin{tabular}{|l|c|}
\hline variables & \\
\hline Age (mean \pm SD) & $38.98 \pm 8.69$ \\
\hline Work duration (mean \pm SD) & $12 \pm 7.76$ \\
\hline Gender & $105(75 \%)$ \\
Male & $35(25 \%)$ \\
Female & \\
\hline Residence & $14(10 \%)$ \\
Rural & $126(90 \%)$ \\
Urban & $7(5 \%)$ \\
\hline Education & $9(6.4 \%)$ \\
Illiterate & $32(22.9 \%)$ \\
Read and write & $43(30.7 \%)$ \\
School & $49(35 \%)$ \\
Technical education & \\
University & $40(28.6 \%)$ \\
\hline Work type & $79(56.4 \%)$ \\
Cook & $21(15 \%)$ \\
Helper & $95(67.9 \%)$ \\
Waiter & $76.63 \pm 19.6$ \\
\hline Current smoker & $68.1 \pm 22.4$ \\
yes & \\
\hline Mean knowledge score & \\
\hline Mean practice score & \\
\hline
\end{tabular}

The current study included 140 workers with mean age $38 \pm 8.6$ and mean work duration of 12 years $\pm 7.7,75 \%$ were males, $90 \%$ from urban areas, $16 \%$ illiterate/read and write, $32 \%$ with school education, $65.7 \%$ technical and university education so majority were educated. Most of them were cook helpers and smokers. Mean knowledge and practice scores were high. (Table 1) 


\section{Table (2): Relationship between type of work and knowledge questions}

\begin{tabular}{|c|c|c|c|c|c|}
\hline Questions & $\begin{array}{c}\text { Cook } \\
\text { No }(\%)\end{array}$ & $\begin{array}{l}\text { Helper } \\
\text { No }(\%)\end{array}$ & $\begin{array}{l}\text { Waiter } \\
\text { No }(\%)\end{array}$ & $\begin{array}{l}\text { Total correct } \\
\text { answers } \\
\text { No }(\%)\end{array}$ & P value \\
\hline $\begin{array}{l}\text { 1-Food poisoning is caused by } \\
\text { pathogenic microbes }\end{array}$ & $37(92.5)$ & 74(93.7) & 21(100) & $132(94.3)$ & $>0.05$ \\
\hline $\begin{array}{l}\text { 2-Risk of food poisoning increases if } \\
\text { food is half cooked }\end{array}$ & $32(80)$ & $73(92.4)$ & $14(66.7)$ & $119(85)$ & $\leq 0.05^{*}$ \\
\hline $\begin{array}{l}\text { 3-Eating unwashed vegetables } \\
\text { increases the risk of food poisoning }\end{array}$ & $38(95)$ & 79(100) & $18(85.7)$ & 135 (96.4) & $\leq 0.05^{*}$ \\
\hline $\begin{array}{l}\text { 4-Unhygienic practice of food } \\
\text { handlers could be the source of food } \\
\text { contamination }\end{array}$ & $37(92.5)$ & $79(100)$ & $15(71.4)$ & 131 (93.6) & $\leq 0.05^{*}$ \\
\hline $\begin{array}{l}\text { 5-Eating covered food after six hours } \\
\text { left at room temperature is a risk for } \\
\text { food poisoning }\end{array}$ & $26(65)$ & $69(87.3)$ & $16(76.2)$ & $111(79.3)$ & $\leq 0.05^{*}$ \\
\hline $\begin{array}{l}\text { 6-Keeping food at refrigerator } \\
\text { temperature reduces the risk of food } \\
\text { poisoning }\end{array}$ & $34(85)$ & $65(82.3)$ & $19(90.5)$ & $118(84.3)$ & $>0.05$ \\
\hline $\begin{array}{l}\text { 7-Touching ready to eat food with } \\
\text { bare hands could be the source of its } \\
\text { contamination }\end{array}$ & $34(85)$ & $69(87.3)$ & $15(71.4)$ & $118(84.3)$ & $>0.05$ \\
\hline $\begin{array}{l}\text { 8-The correct method for thawing } \\
\text { frozen food is to keep it overnight at } \\
\text { room temperature }\end{array}$ & $22(55)$ & $25(31.6)$ & $12(57.1)$ & $59(42.1)$ & $\leq 0.05^{*}$ \\
\hline $\begin{array}{l}\text { 9-Food poisoning could cause severe } \\
\text { diseases that end in hospitalization } \\
\text { or death }\end{array}$ & $32(80)$ & $65(82.3)$ & $16(76.2)$ & $113(80.7)$ & $>0.05$ \\
\hline $\begin{array}{l}\text { 10-Apparaently healthy food } \\
\text { handlers could be carriers of food } \\
\text { borne pathogens }\end{array}$ & $30(75)$ & $66(83.5)$ & $15(71.4)$ & $111(79.3)$ & $>0.05$ \\
\hline $\begin{array}{l}\text { 11-Insects such as cockroaches and } \\
\text { flies could transmit food borne } \\
\text { pathogens }\end{array}$ & $31(77.5)$ & 71(89.9) & $18(85.7)$ & $120(85.7)$ & $>0.05$ \\
\hline $\begin{array}{l}\text { 12-Harmful bacteria multiply } \\
\text { rapidly at room temperature }\end{array}$ & $38(95)$ & $65(82.3)$ & 13(61.9) & 116 (82.9) & $\leq 0.05^{*}$ \\
\hline $\begin{array}{l}\text { 13-Food borne pathogens could be } \\
\text { seen by naked eye }\end{array}$ & $16(40)$ & $50(63.3)$ & $7(33.3)$ & $73(52.1)$ & $\leq 0.05^{*}$ \\
\hline $\begin{array}{l}\text { 14-Vegetables should be placed at } \\
\text { a higher shelf in refrigerator than } \\
\text { meat and poultry }\end{array}$ & $22(55)$ & $12(15.2)$ & $12(57.1)$ & $46(32.9)$ & $\leq 0.05^{*}$ \\
\hline
\end{tabular}

*: Statistically significant

Less than $50 \%$ of participants gave correct answers to questions related to correct method of thawing food and right places for vegetables and meat in the refrigerator. Significant difference between types of food handlers was found in answering some knowledge questions (Table 2) 
Table (3): Relationship between type of work and response to practice questions:

\begin{tabular}{|c|c|c|c|c|c|}
\hline Questions & $\begin{array}{c}\text { Cook } \\
\text { No }(\%)\end{array}$ & $\begin{array}{l}\text { Helper } \\
\text { No }(\%)\end{array}$ & $\begin{array}{r}\text { Waiter } \\
\text { No }(\%)\end{array}$ & $\begin{array}{l}\text { Hygienic } \\
\text { practice } \\
\text { No }(\%)\end{array}$ & Pvalue \\
\hline $\begin{array}{l}\text { 1- Do you wear gloves when you handle } \\
\text { ready to eat food or prepare food? }\end{array}$ & $30(75)$ & $50(63.3)$ & $14(66.7)$ & $94(67.1)$ & $>0.05$ \\
\hline $\begin{array}{l}\text { 2-Do you wash your hands with soap and } \\
\text { water before preparing food? }\end{array}$ & $33(82.5)$ & $69(87.3)$ & $16(76.2)$ & $118(84.3)$ & $>0.05$ \\
\hline $\begin{array}{l}\text { 3-Do you wash your hands with soap and } \\
\text { water after using the bathroom? }\end{array}$ & $34(85)$ & $67(84.8)$ & 13(61.9) & $114(81.4)$ & $\leq 0.05^{*}$ \\
\hline $\begin{array}{l}\text { 4-Do you wash vegetables and fruits before } \\
\text { slicing them? }\end{array}$ & $33(82.5)$ & $64(81)$ & $18(85.7)$ & $115(82.1)$ & $>0.05$ \\
\hline $\begin{array}{l}\text { 5-Do you not keep cooked food at room } \\
\text { temperature for more than four hours? }\end{array}$ & $19(47.5)$ & $28(35.4)$ & $6(28.6)$ & 53 (37.9) & $>0.05$ \\
\hline $\begin{array}{l}\text { 6-Do you clean food contacting surfaces } \\
\text { before using them? }\end{array}$ & $35(87.5)$ & 70(88.6) & $19(90.5)$ & 124 (88.6) & $>0.05$ \\
\hline $\begin{array}{l}\text { 7-Do you clean food contacting surfaces } \\
\text { after using them? }\end{array}$ & $40(100)$ & 77(97.5) & $20(95.2)$ & 137 (97.9) & $>0.05$ \\
\hline $\begin{array}{l}\text { 8-Do you separate raw food from ready to } \\
\text { eat food? }\end{array}$ & $36(90)$ & $74(93.7)$ & $19(90.5)$ & $129(92.1)$ & $>0.05$ \\
\hline $\begin{array}{l}\text { 9-Do you regularly check the temperature } \\
\text { of the refrigerator? }\end{array}$ & $33(82.5)$ & $56(70.9)$ & $18(85.7)$ & 107 (76.4) & $>0.05$ \\
\hline $\begin{array}{l}\text { 10-Do you boil raw unpasteurized milk } \\
\text { before use? }\end{array}$ & $23(57.5)$ & $58(73.4)$ & $7(33.3)$ & $88(62.9)$ & $\leq 0.05^{*}$ \\
\hline $\begin{array}{l}\text { 11-Do you check the expiry date of } \\
\text { ingredients you use in cooking before } \\
\text { using them? }\end{array}$ & $22(55)$ & $58(73.4)$ & $14(66.7)$ & $94(67.1)$ & $>0.05$ \\
\hline $\begin{array}{l}\text { 12-Do you not continue work if you have } \\
\text { a flu? }\end{array}$ & $13(32.5)$ & $30(38)$ & $11(52.4)$ & 54 (38.6) & $>0.05$ \\
\hline $\begin{array}{l}\text { 13-Do you not continue work if you have } \\
\text { diarrhea? }\end{array}$ & $10(25)$ & $34(43)$ & $8(38.1)$ & $52(37.1)$ & $>0.05$ \\
\hline $\begin{array}{l}\text { 14- Do you not continue work if you have } \\
\text { lesions on your hands? }\end{array}$ & $7(17.5)$ & $29(36.7)$ & $4(19)$ & 40 (28.6) & $\leq 0.05^{*}$ \\
\hline $\begin{array}{l}\text { 15-Did you have a pre employment } \\
\text { examination? }\end{array}$ & $29(72.5)$ & 71(89.9) & $11(52.4)$ & $111(79.3)$ & $\leq 0.05^{*}$ \\
\hline $\begin{array}{l}\text { 16-Do you have periodic medical } \\
\text { examination? }\end{array}$ & $23(57.5)$ & $65(82.3)$ & $9(42.9)$ & 97 (69.3) & $\leq 0.05^{*}$ \\
\hline
\end{tabular}

*: Statistically significant

Less than $50 \%$ of participants gave correct answers to questions related to keeping food at room temperature for more than 4 hours, continuing work while having flu or hand lesions. Significant difference between types of food handlers was found in answering some practice questions (Table 3) 
Table (4): Response of food handlers to attitude questions on food poisoning:

\begin{tabular}{|l|c|c|}
\hline & $\begin{array}{c}\text { Agree } \\
\text { No (\%) }\end{array}$ & $\begin{array}{c}\text { Disagree } \\
\text { No (\%) }\end{array}$ \\
\hline $\begin{array}{l}\text { 1- Safe food handling is an important part of my job } \\
\text { responsibilities }\end{array}$ & $131(93.6)$ & $9(6.4)$ \\
\hline $\begin{array}{l}\text { 2- It is important to wear gloves during work } \\
\text { 3- Learning more about food safety through training courses is } \\
\text { important to me. }\end{array}$ & $100(71.4)$ & $40(28.6)$ \\
\hline $\begin{array}{l}\text { 4- I prefer cutting my nails regularly because long nails could } \\
\text { contaminate food }\end{array}$ & $125(89.3)$ & $15(10.7)$ \\
\hline $\begin{array}{l}\text { 5- I think that periodic medical for food handlers every six } \\
\text { months is essential }\end{array}$ & $116(82.9)$ & $24(17.1)$ \\
\hline
\end{tabular}

Most of food handlers showed a good attitude. They believed that safe food handling was an important part of their job responsibility, it was important to wear gloves, most of them agreed on the need for training courses, prefer regular nail cutting and believed periodic medical examination was essential every 6 months (Table 4) 
Table (5): Description of the participants who have positive culture:

\begin{tabular}{|l|c|}
\hline Skin swab test & No $(\%)$ \\
\hline Positive & $22(40.7)$ \\
Negative & $32(59.3)$ \\
\hline Type of organism & \\
Staphylococcus aureus & $6(27.2)$ \\
Coagulase negative staphylococci & $9(41)$ \\
Diphteroids & $6(27.2)$ \\
Candida albicans & $1(4.6)$ \\
\hline Job nature: & \\
Cook & $7(31.8)$ \\
Helper & $14(63.6)$ \\
Waiter & $1(4.5)$ \\
\hline Gender & $17(77.3)$ \\
Male & $5(22.7)$ \\
Female & $16(72.7)$ \\
\hline Current smoker & \\
\hline Nail cutting & $4(18.2)$ \\
Twice weekly & $12(54.5)$ \\
Once weekly & $6(27.3)$ \\
Once biweekly & $40.32 \pm 8.54$ \\
\hline Age (mean \pm SD) & $13.14 \pm 6.70$ \\
\hline Work duration (mean \pm SD) & $3(13.6)$ \\
\hline Education & $2(9.1)$ \\
Illiterate & $9(36.4)$ \\
Read and write & $9(40.9)$ \\
School & \\
University & \\
\hline & \\
\hline
\end{tabular}

The majority (40.7\%) of those who agreed to have nail swabs showed positive culture mainly to Coagulase negative staphylococci. Most of them were cook helpers, males, educated, current smokers, cut nails once weekly with mean age $40.3 \pm 8.5$ and mean work duration of $13.14 \pm 6.7$ (Table 5) 
Table (6): Relationship between work duration and mean knowledge and practice scores:

\begin{tabular}{|c|c|c|c|c|}
\hline & Work duration & Number & Mean \pm SD & $P$ value \\
\hline Mean knowledge score & $\begin{array}{c}12 \text { years } \\
\geq 12 \text { years }\end{array}$ & $\begin{array}{l}80 \\
59\end{array}$ & $\begin{array}{l}10.45 \pm 1.81 \\
11.10 \pm 1.36\end{array}$ & $\leq 0.05^{*}$ \\
\hline Mean practice score & $\begin{array}{c}12 \text { years } \\
\geq 12 \text { years }\end{array}$ & $\begin{array}{l}80 \\
59\end{array}$ & $\begin{array}{c}9.88 \pm 2.31 \\
12.20 \pm 2.10\end{array}$ & $\leq 0.05^{*}$ \\
\hline
\end{tabular}

*: Statistically significant

Mean knowledge and practice scores of the study participants were significantly higher among those with longer work duration ( $\geq 12$ years) than among those with work duration less than 12 years (Table 6)

\section{Discussion}

The current study included 140 workers with mean age $38 \pm 8.6$ and mean work duration of 12 years \pm 7.7 , $75 \%$ were males, $90 \%$ from urban areas, $16 \%$ illiterate/read and write, $32 \%$ with school education, $65.7 \%$ technical and university education so majority were educated (Table 1). Most of them were cook helpers and smokers. Mean knowledge and practice scores were high. In a study by Rekha and Masali (2007), they found that $73.2 \%$ of respondents were below 30 years of age and only $2.7 \%$ were above 50 years of age. They stated that the majority of respondents with good personal hygiene belonged to the age of 30-39 years which is the mean age of the current study population who also showed a high mean practice score. In their study also, it was observed that good personal hygiene was often practiced among the highly educated workers than among illiterates. This may explain also the high mean practice score in the current study where most of participants were educated.

\section{Food handler's knowledge:}

Food handlers demonstrated satisfactory knowledge in the categories of

Questions of high risk foods as: half cooked foods, unwashed vegetables, covered foods left for more than 6 hours at room temperature.

- Questions on food borne diseases as: food poisoning is caused by pathogens, food poisoning could 
lead to hospitalization, apparently healthy workers could be carriers, insects and flies could transmit pathogens.

- Questions food storage temperatures as: food is best kept in the refrigerator; harmful bacteria could multiply at room temperature.

- Questions about the sources of food contamination as unhygienic practice of food handlers, touching ready to eat food with bare hands.

More than half of the food handlers (58\%) chose that the correct method for thawing frozen food is to keep it overnight at room temperature. Similar results were obtained by other studies (Annor and Baiden, 2011, Sharif et al, 2013). Keeping meat and poultry cold while it is defrosting is essential. Bacterial growth is expected to increase if food is thawed at room temperature, and consequently the probability of food poisoning. Hence the best way to safely thaw frozen food is in the refrigerator or applying defrost program in the microwave (United States Department of Agriculture, 2006).

Some basic knowledge is defective where about half of the participants mentioned that food borne pathogens could be seen by naked eye. Similarly, other studies showed that between $52.5 \%$ and $64.4 \%$ wrongly believed that they can detect food contamination with bacteria by visual, olfactory or taste checks (Gomes-Neves et al, 2007, Jev凹ik et al, 2008, Martins et al, 2012 and Walker et al, 2003). Unlikely, another study carried out among food handlers in military hospitals in Jordan (Sharif et al, 2013) showed that food handlers correctly answered the same question.

Also, regarding the question of placing vegetables on a higher shelf in the refrigerator than meat and poultry, $54 \%$ of the participants gave an incorrect answer. Sharif et al (2013) had different results where $85 \%$ of their study participants had correctly chosen the answer. Improper storage of ready to eat food facilitates the growth of Listeria monocytogenes to an infectious level. Specifically, improper holding temperature and slow cooling of hot foods promote growth of $\mathrm{B}$. cereus and $\mathrm{Cl}$. Perfringes to levels causing diseases (McCabe-Sellers and Beatti, 2004).

In general, the food handlers had good knowledge on hygiene measures with a mean percentage score of $76.6 \%$ $\pm 19.6 \%$. These results were similar to 
another study carried out in military hospitals in Jordan (Sharif et al, 2013). On the other hand, in South Africa (Marais et al, 2007) and in Turkey (Bas et al, 2006) the mean scores were much lower ( $46 \%$ and $43 \%$ respectively).

\section{Regarding their practice:}

Seventy eight percent of the study participants regularly checked the temperature of the refrigerator, while $38 \%$ only avoid keeping cooked food at room temperature for more than four hours. This discrepancy between knowledge and practice was also agreed by other researchers (Nee and Norrakiah 2011) who found that the majority of the respondents have an average practices in all parts of the questions, despite their good knowledge. In their study, they found that the participants had good knowledge on personal hygiene and definition of food borne diseases (94\% and $74 \%$, respectively). On the contrary, their knowledge on temperature control was poor with only $28 \%$. In Jordan, a study showed that the food handlers have a good knowledge of temperature control and they practiced such knowledge (Sharif et al, 2013). Other studies carried out in Turkey, Portugal, United Kingdom, Slovenia and Italy demonstrated that food handlers are defective in knowledge concerning the importance of temperature control in practicing food handling hygienic measures (Bas et al, 2006, Buccheri et al, 2007, Marais et al, 2007, Gomes-Neves et al, 2007, Jev—ik et al, 2008, Walker E et al, 2003). Improper temperature control of fresh or cooked food promotes growth of food borne pathogens (McCabeSellers and Beatti, 2004).

In this study, washing hands with soap and water before preparing food and after using the bathroom was $84 \%$ and $81 \%$ respectively. Similar findings were obtained by Buccheri et al (2007) where about $80 \%$ of food handlers in their study always washed their hands before and after food handling. Some studies showed very low frequency of hand washing (Okojie et al, 2012). Other studies showed significant increase in knowledge about hand hygiene measures, namely, washing hands before handling food ( $23.5 \%$ to $65.4 \%$ ) after carrying out a health education session ( Malhotra et al, 2008).

The majority of the study participants reported working while having flu, diarrhea or skin lesions $(61 \%, 63 \%$ and $71 \%$ respectively). In other studies, $40 \%$ of food handlers continued 
working while having diarrhea, while $80 \%$ of them would handle food during an attack of fever (Annor and Baiden 2011). Lower rate was reported by Black (1999) where $5 \%$ of food handlers in his study continued working while sick with vomiting or diarrhea. In another study Buccheri et al (2007), 15\% only worked while having skin lesions. Food and drug administration (FDA, 2013 b) mentioned that any food handler should stop working while having diarrhea until 24 hours after diarrhea resolution.

In general, the food handlers practiced good hygiene level with a mean percentage score of $68.1 \%$ $\pm 22.4 \%$. Nearby result $(72 \%)$ was mentioned by Cuprasitrut et al (2011). Much higher result (89\%) was reached in another study (Sharif et al, 2013).

In the current study, 22 participants (41\%) had positive nail swabs. Those are distributed as follows; $9(17 \%)$ were infected with CoNS, $6(11 \%)$ with Staphylococcus aureus, 6 (11\%) with Diphteroids and only 1 case of candida albicans (Table 5). A study in Egypt had a similar infection rate with staph aureus (38\%) (El-Shenawy et al, 2014)

It was mentioned that $\mathrm{S}$. aureus colonization rates in the general population were estimated to be approximately 20\% - 32\%. (Wertheim et al, 2005). Regarding studies specific for food handlers, prevalence rates vary among countries. It ranged from $2 \%$ of food handlers in a study done in Italy (Talarico et al, 1997), 12\% in Finland (Hatakka, 2000), 16.5\% in Ethiopia (Andargie et al, 2008), 19\% in Chile (Figueroa et al, 2002), 57.5\% in Botswana (Loeto et al, 2007) and 62\% in India (Simon and Sanjeev, 2007).

It was found that food handlers who were more experienced had better mean knowledge and practice scores. This was also agreed by other researchers (Sharif et al, 2013) and (Tang and Fong, 2004). Another study done by Buccheri et al, 2007 reported a relation between work duration and some items of knowledge and practice with a significant difference.

Regarding a comparison between workers as regards the type of work they do and their correct answers to knowledge questions, it was found that the percentage of helpers giving correct answers to queries about "Unhygienic practice of food handlers could be the source of food contamination", "Eating covered food after six hours left at room temperature is a risk for food poisoning" 
and "food borne pathogens could be seen by naked eye" were significantly higher than that of other work types. The percentages of waiters answering correctly queries about "the correct method for thawing frozen food is to keep it overnight at room temperature" and "vegetables should be placed at a higher shelf in refrigerator than meat and poultry" was significantly higher than that among other categories and the percentage of cooks answering correctly the query about "harmful bacteria multiply rapidly at room temperature" was significantly higher than that among helpers and waiters.

Regarding the comparison in practice questions, the cooks who correctly washed their hands with soap and water after using the bathroom and the helpers who discontinued work if they had lesions on their hands showed a significantly higher percentage than other work types.

This discrepancy according to work types agrees with the findings of other work which showed variability in answers according to work types (Sharif et al, 2013)

Regarding their attitude, they have general positive attitude towards safe food handling measures. The majority are willing to attend food safety training courses. The benefits of such training was confirmed also by some researchers after a meta-analysis study where they concluded that food safety training increased knowledge and improved attitudes about hand hygiene practices. Refresher training and long-term reinforcement of good food handling behaviors may also be beneficial for sustaining good hand washing practices (Soon et al, 2012.)

\section{Limitations}

Limitations of this study include inability to perform nail swabs to all study participants.

Recommendations

It is recommended that food premises should imply training programs to food handlers concerning proper food hygiene practices. This will have an important role in improving their knowledge, attitude and practice about food sanitation, especially if this is associated with concurrent supervision to ensure the effectiveness of such programs.

Regarding academic research, further wider studies are recommended to be carried out both hospital 
and community based to measure knowledge of food handlers with the required bacteriological examination.

\section{References}

1. Adams MR and Moss MO (2008): Food microbiology, third edition. The Royal Society of Chemistry, Cambridge.

2. Andargie G, Kassu A, Moges F, Tiruneh M and Huruy K (2008): Prevalence of Bacteria and Intestinal Parasites among Food-Handlers in Gondar Town, Northwest Ethiopia. Journal of Health, Population and Nutrition; 26: 451- 55.

3. Annor GA and Baiden EA (2011): Evaluation of Food Hygiene Knowledge Attitudes and Practices of Food Handlers in Food Businesses in Accra, Ghana. Food and Nutrition Sciences; 2: 830-6.

4. Bas M, Ersun A and Kivanç G (2006): The Evaluation of Food Hygiene Knowledge, Attitudes, and Practices of Food Handlers' in Food Businesses in Turkey, Food Control; 17(4):317-22.

5. Black JG (1999) :Microbiology: Principles and Explora-tions,4th Edition, Prentice Hall, Upper Saddle River, pp. 386-600

6. Buccheri C, Casuccio A, Giammanco S, La Guardia M, and Mammina C (2007): Food safety in hospital: knowledge, attitudes and practices of nursing staff of two hospitals in Sicily, Italy. BMC Health Serv Res; 7(45):1-11.

7. Çakiroglu FP and Uçar A (2007): "Employees' Perception of Hygiene in the Catering Industry in Ankara (Turkey)." Food Control; 19(1): 9-15.

8. Collee JG, Miles RS, Watt B (2007): Tests for identification of bacteria. In: Collee JG, Fraser AG, Marmion BP, Simmons A (eds): Mackie and McCartney Practical Medical Microbiology, 14th edition, pp.1003-4.

9. Cuprasitrut $\mathrm{T}$, Srisorrachatr $\mathrm{S}$ and Malai D (2011): Food Safety Knowledge, Attitude and
Practice of Food Handlers and Microbiological and Chemical Food Quality Assessment of Food for Making Merit for Monks in Ratchathewi District, Bangkok. Asia. Journal of Public Health; 2(1):27-34.

10. El-Shenawy M, Tawfeek M, El-Hosseiny L, El-Shenawy M, Farag A, Baghdadi H, Saleh O, Mañes J, Soriano JM (2014): Cross Sectional Study of Skin Carriage and Enterotoxigenicity of Staphylococcus aureus among Food Handlers. Open Journal of Medical Microbiology; 4: 16-22.

11. FDA (2013a): Food. Chapter 1: Purpose and definitions. Available at: http:// www.fda.gov/Food/GuidanceRegulation/ RetailFoodProtection/FoodCode/ucm186464. htm

12. FDA (2013 b): Employee Health and Personal Hygiene Handbook. Available at http://www.fda.gov/Food/ GuidanceRegulation/RetailFoodProtection/ IndustryandRegulatoryAssistanceand

13. TrainingResources/ucm 113827.htm

14. Figueroa G, Navarrete P, Caro M, Troncoso $M$ and Faundez G (2002): Carriage of Enterotoxigenic Staphylococ- cus aureus in Food Handlers. Revista Medica de Chile; 130: 859-64.

15. Gomes-Neves E, Araújo AC, Ramos E and Cardoso CS (2007): Food Handling: Comparative Analysis of General Knowledge and Practice in Three Relevant Groups in Portugal, Food Control; 18(6): 707-12.

16. Hatakka M, Björkroth KJ, Asplund K, MäkiPetäys N and Korkeala HJ (2000): Genotypes and Enterotoxicity of Staphylococcus aureus Isolated from the Hands and Nasal Cavities of Flight-Catering Employees. Journal of Food Protection; 63: 1487-91.

17. Isara AR and Isah EC (2009): Knowledge and practice of food hygiene and safety among food handlers in fast food restaurants in Benin City, Edostate, Niger. Postgraduate Medical Journal; 16(3):207-12 
18. Jev[ik M, Hlebec V and Raspor P (2008): Safety Knowledge and 553 Practices among Food Handlers in Slovenia. Food Control; 19(12): 1107-11.

19. Loeto D, Matsheka MI and Gashe BA (2007): Enterotoxigenic and Antibiotic Resistance Determination of Staphylococcus aureus Strains Isolated from Food Handlers in Gaborone, Botswana. Journal of Food Protection; 70: 2764-8.

20. Malhotra R, Lal P, Prakash SK, Daga MK, Kishore J (2008): Evaluation of a health education intervention on knowledge and attitudes of food handlers working in a medical college in Delhi, India. Asia Pac J Public Health; 20(4):277-86.

21. Marais $\mathrm{M}$, Conradie $\mathrm{N}$ and Labadarios $\mathrm{D}$ (2007): Small and Micro Enterprises - Aspects of Knowledge, Attitudes and Practices of Managers' Hospital, Western Cape, South African Journal Clinical Nutrition; 20, (2):5061.

22. Martins RB, Hogg T and Otero JG (2012): Food Handlers' Knowledge on Food Hygiene: The Case of a Catering Company in Portugal, Food Control; 23(1): 184-90.

23. McCabe-Sellers BJ and Beattie SE (2004): Food Safety: Emerging Trends in Food Borne Illness Surveillance and Prevention, Journal of the American Dietetic Association; 104 (11):1708-17.

24. Mead PS, Slutsker L, et al (1999): Food related illness and death in the United States. Emerging Infectious Diseases; 5:607-25.

25. Mohan V (2001): An evaluation of health status of food handlers of eating establishments in various educational and health institution in Amritsar city. Indian Journal of Community Medicine; 26, 80-5.

26. Nee SO and Norrakiah AS (2011): Assessment of Knowledge, Attitudes and Practices (KAP) among Food Handlers at Residential Colleges and Canteen Regarding Food Safety, Sains Malaysiana ; 40(4):403-10.

27. Okojie $\mathrm{OH}$, Wagbatsoma VA, Ighoroge $\mathrm{AD}$ (2005): An assessment of food hygiene among food handlers in a Nigerian university campus. Niger Postgrad Med J; 12(2):93-6.

28. Rekha SU and Masali KA (2007): A study on the health status of food handlers employed in food establishments in Bijapur city. Indian $\mathrm{J}$ Community Med; 32:131-2.

29. Schlundt J, Toyofuku H, Jansen J, Herbst SA (2004): Emerging food borne zoonoses. Rev Science Tech; 23:513-515

30. Sharif L, Obaidat MM, Al-Dalalah MR (2013): Food Hygiene Knowledge, Attitudes and Practices of the Food Handlers in the Military Hospitals. Food and Nutrition Sciences 4: 24551.

31. Simon SS and Sanjeev S (2007): Prevalence of Enterotoxigenic Staphylococcus aureus in Fishery Products and Fish Processing Factory Workers. Food Control; 18:1565-8.

32. Soon JM, Baines R, Seaman P (2012): Metaanalysis of food safety training on hand hygiene knowledge and attitudes among food handlers. J Food Prot; 75(4):793-804.

33. Talarico F, Roccia E and Nero D (1997): "Prevalence of Enterotoxigenic Staphylococcus in Food Handlers in the Province of Catanzaro (Italy): Igiene Moderna; 107: 137-142.

34. Tang CHI and Fong UV (2007): A survey of food hygiene knowledge and attitudes among Chinese food handlers in Fong Song Tong district. Asia Pac J Public Health; 16(2):121-5.

35. Todd EC, Greig JD, Bartleson CA and Michaels BS (2007): Outbreaks where food handlers have been implicated in the spread of food borne disease, part 3 factors contributing to outbreaks and description of outbreak categories. Journal of food protection; 70(9): 2199-217. 
36. United States Department of Agriculture, Fact Sheets on Safe Food Handling, (2006): http:// www.fsis.usda.gov/FactSheets/Smoking_ Meat_and_Poultry/index.asp

37. Walker E, Pritchard C and Forsythe S (2003): Food Handlers' Hygiene Knowledge in Small Food Businesses, Food Control; 14(5): 339-43.

38. Wertheim HFL, Melles DC, Vos MC, van Leeuwen W, van Belkum A, Verbrugh HA and
Nouwen JL (2005): The Role of Nasal Carriage in Staphylococcus aureus Infections." Lancet Infectious Diseases; 5:751-62.

39. Zain MM and Naing NN (2002): Sociodemographic characteristics of food handlers and their knowledge, attitude and practice towards food sanitation. South-East Asian Journal of Tropical Med Public Health; 33(2):410-7. 